\title{
PARA ROCÍO JURADO
}

Fabrício Trindade

José Alberto In Concert

Fabrício Trindade - Artista múltiplo que trabalha nas mais diversas áreas de criação para a cena (atuação, direção,

figurino, cenário, etc.), já trabalhou com diversos coletivos e grupos, desenvolvendo funções que sempre o colocaram nas fronteiras de linguagens e de disciplinas artísticas. É

Doutorando na Escola de Belas Artes da Universidade Federal de Minas Gerais e professor no Teatro Universitário da UFMG.
José Alberto In Concert - Nascido em 1952. Cabelereiro,

Maquiador, Artista Plástico e ator transformista. 38 anos de

carreira. Trabalhos realizados em várias casas de shows em $\mathrm{BH}$ RJ e SP. 


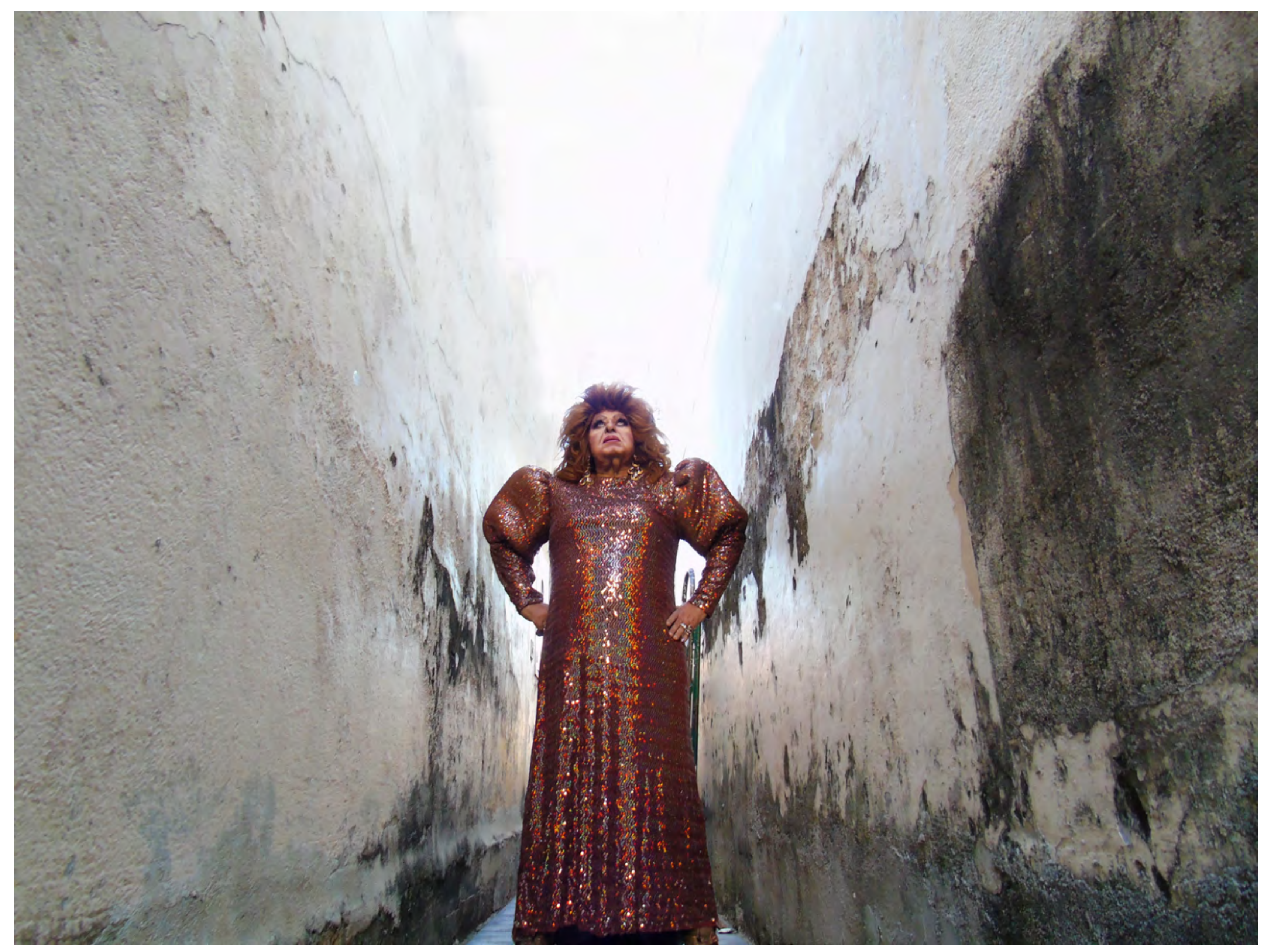




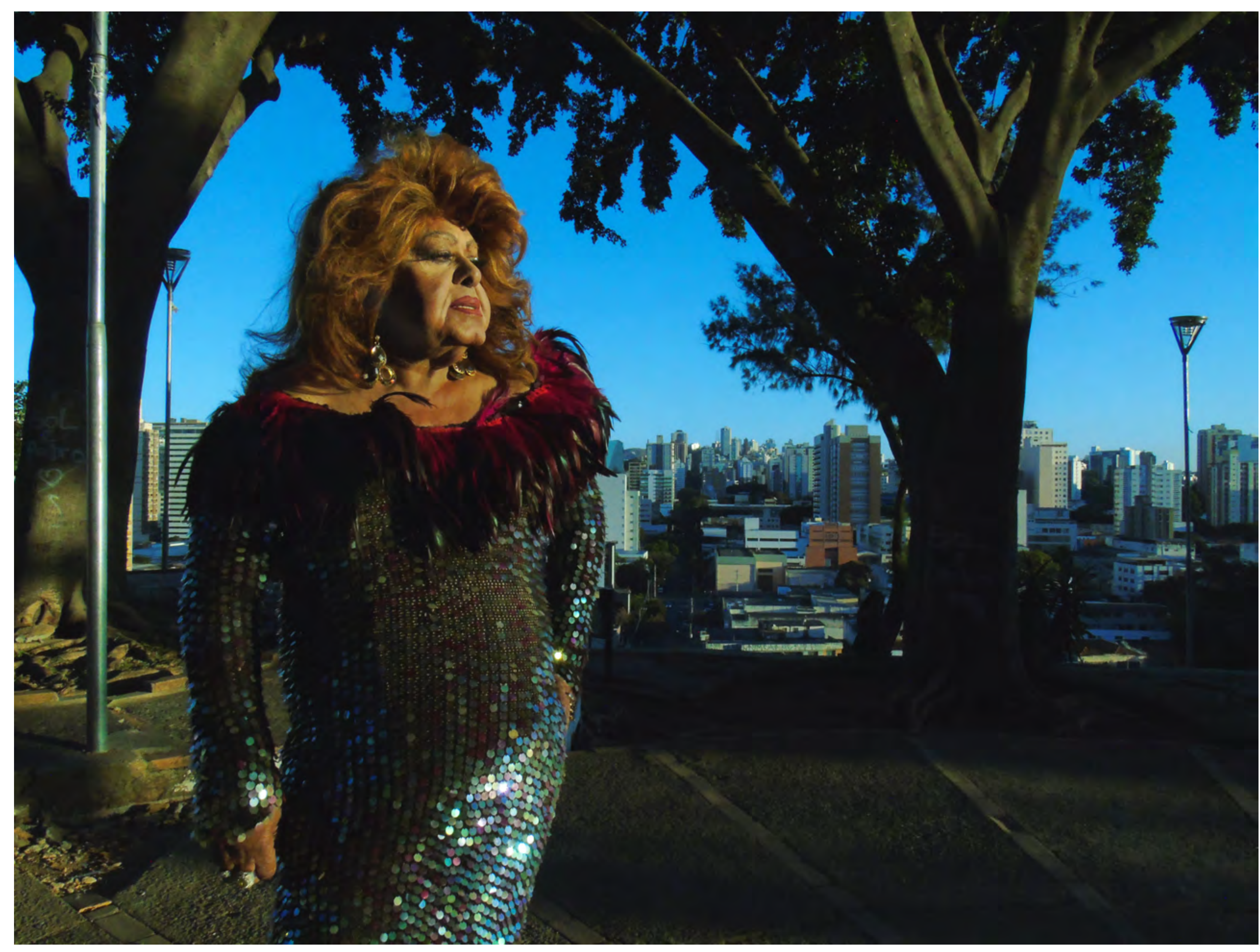




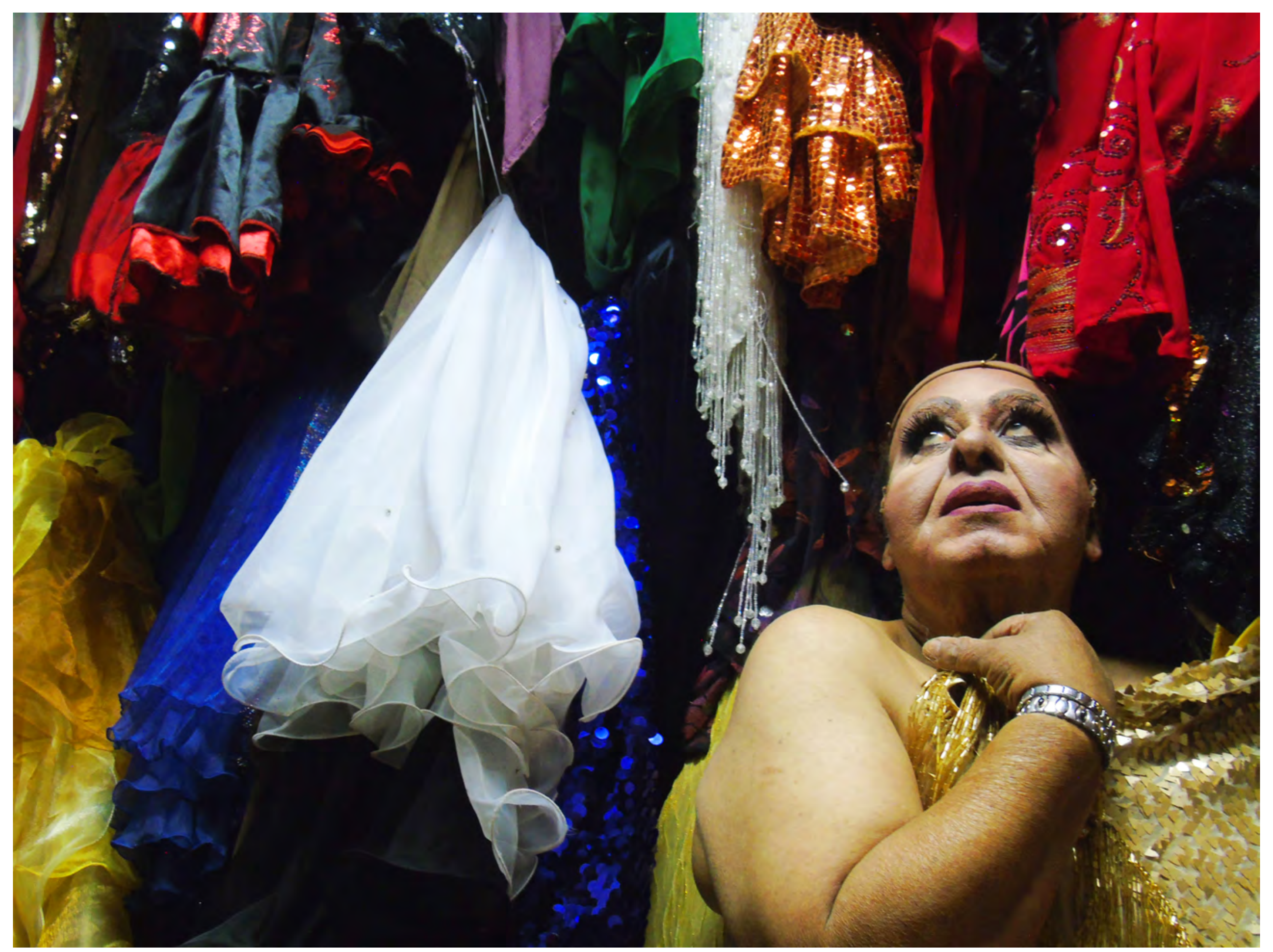




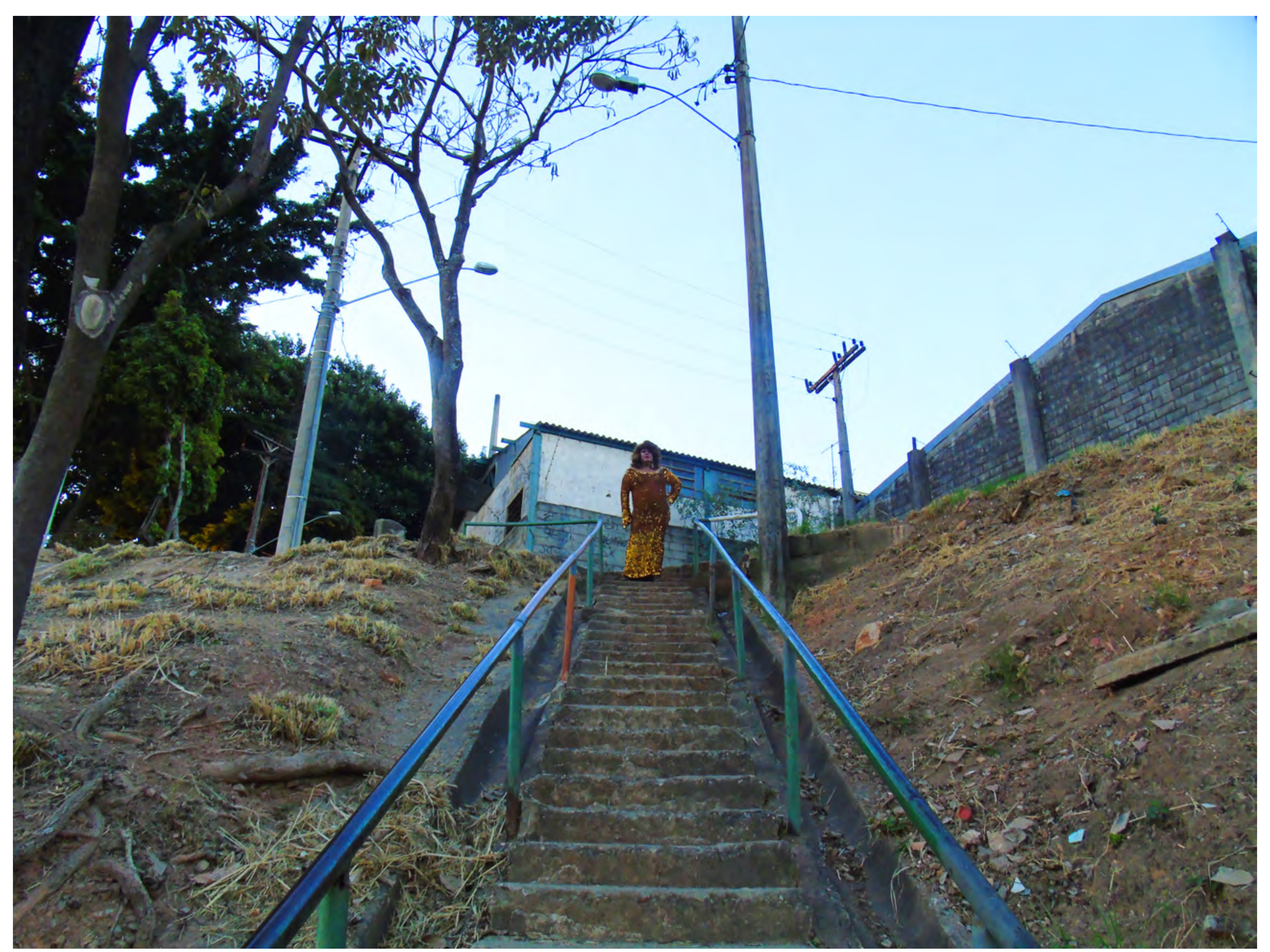




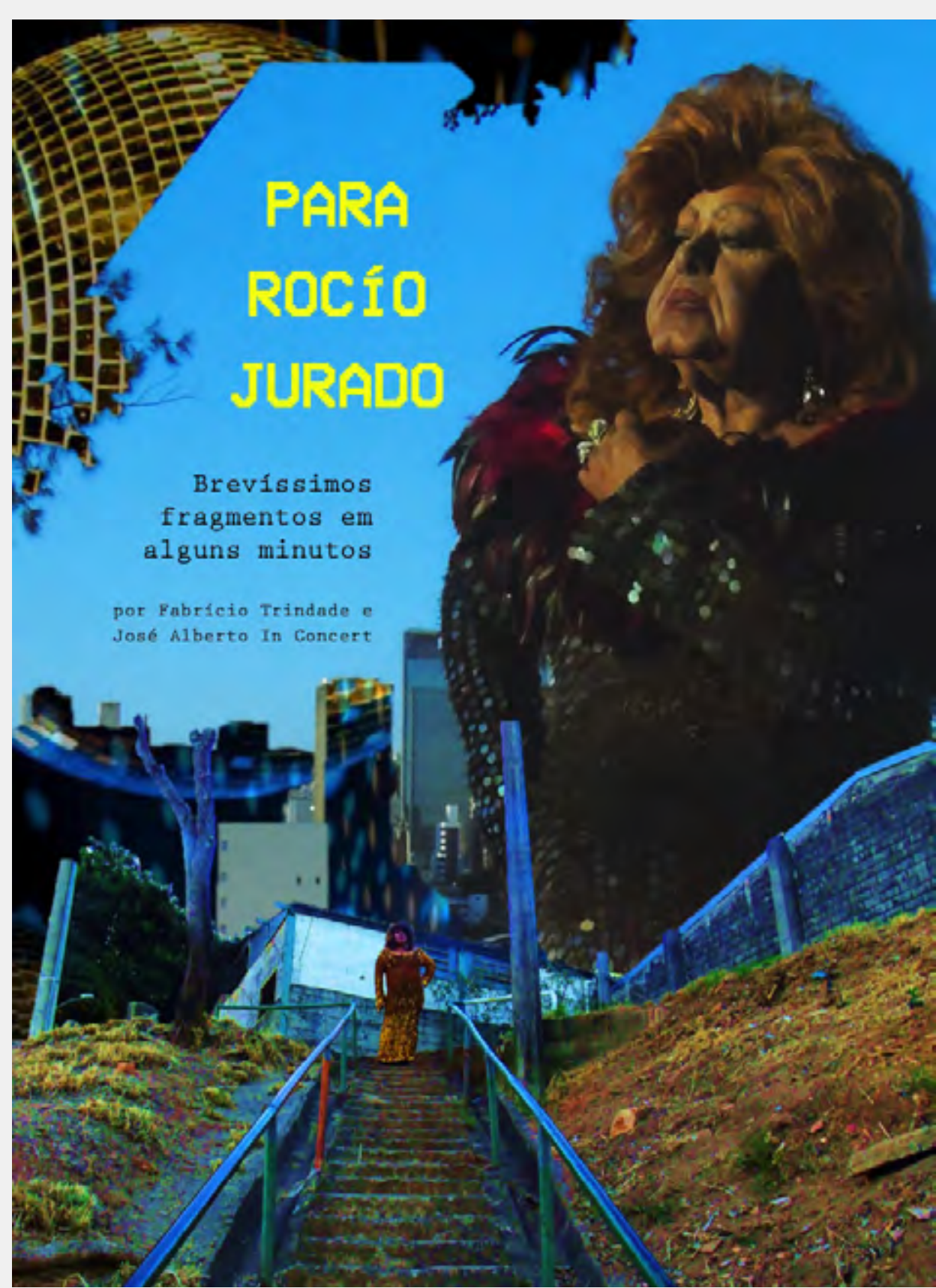

\section{PARA ROCIO JURADO}

BREVÍSSIMOS FRAGMENTOS EM ALGUNS MINUTOS

\section{por Fabrício Trindade e José Alberto In Concert}

No ciclorama de um corpo que se rasga, uma diva se projeta. Ela, com a plataforma da altura certa, mistura em sua pele cores e tons do glitter de um estojo antigo. Abrem-se os fechos para emergir narrativas numa exposição de si. Para Rocío Jurado é um tributo, uma dedicatória para que a memória de um país subterrâneo e aferrolhado venha à superfície retocar sua resistência e ajustar seus cílios postiços.

Na rotunda, uma tela branca, de 4 metros por 3 , pendurada à direita.

Ao lado dela, um manequim, vestido com uma capa brilhante, serve de suporte para um microfone e um espelho.

Posicionado, atrás do manequim, um pedestal. Ele tem uma rosa branca colocada em um dos encaixes e pendurado um roupão de seda.

Marcando uma grande diagonal um tapete vermelho cruza o espaço.

Na ponta desse tapete, aquela mais próxima da plateia,

um banco preto e prata. Assentado nesse banco um microfone com fio, 
1. Esta é uma tradução do prólogo dito por Raquel Olmedo música En el escenario. uma taça com um suco verde, um canudinho e um leque.

No outro lado da cena, estão posicionadas uma grade junto à uma mesa, que são apoios para laquê spray, pente, prato pequeno com óleo, toalha, um vestido de paetês e um porta retrato.

O ambiente sugere uma certa intimidade de bastidor e esta composto como um simples espaço peculiar aberto para receber tanto uma visita amigável, como também o público de um trabalho cênico.

00:00 - STOP/PLAY: BREVE FRAGMENTO DE UM PRÓLOGO.

$\mathrm{Na}$ tela branca um vídeo é projetado. Como em filmes VHS, a composição das imagens em movimento se inicia com José Alberto de costas, em frente a um espelho se maquiando. Este trecho se constrói entre a escuridão que toma a cena e o foco de luz que destaca a presença do espelho e reforça uma silhueta do corpo presente. O áudio que se escuta é um texto na voz de José Alberto:

[Na bagunça do meu camarim, na angústia do último momento, na solidão que me arrebata antes de subir ao palco eu deixei todo o meu medo. Agora, eu não sou mais meu. Pertenço-lhes. $]^{1}$

Logo depois desse trecho, um texto amarelo, como as legendas dos filmes dos anos 80/90 aparece entre ruídos:
[Há duas maneiras de se contar uma história: pela superfície ou pelo subterrâneo dela. Ainda tem muita história guardada nos estojos de glitter e sombras antigos. É hora de retocar a resistência e ajustar o cílios, Baby!]

No alto de uma escadaria a diva José Alberto In Concert aparece, em silhueta ta mbém, a té então seu rosto não é revelado. O que se destaca é a escadaria quase infinita, o vestido dourado, o céu azul, a cidade no fundo e os pequenos movimentos dançantes que ela faz ao som de fragmentos de Cry in the Rain, do grupo musical A-ha.

Em cena, quando se inicia essa sequência, um novo movimento se anuncia, $\mathrm{o}$ a tor tra nsformista entra caminhando lentamente, passando em frente a projeção, como se a personagem do vídeo estivesse tomando forma ali, diante de nós. Ela caminha e realiza pausa em gestos que ora se direcionam para o alto, ora se lançam ao chão. Os braços vão compondo essas imagens que o corpo constrói no espaço. Em movimento essa diva vai em direção ao manequim e ao pedestal, ela pega o roupão de seda do cabide e se põe a caminhar no tapete carregando-o, como se carregasse alguém deitado em seu colo. Atravessa toda cena seguindo a diagonal vermelha concretizada pelo tapete, $e$ ao chega ao fim estica os braços, que carregam o vestido, à frente como se oferecesse aquele corpo/roupão aos céus. 
Fim da música do $A$-ha, escuridão no vídeo.

Stop/Play.

Chiados, interferências típicas das fitas VHS.

Tela de listras multicolor.

Uma frase:

[No ciclorama de uma corpo que se rasga, uma diva se projeta.]

Uma última imagem desse vídeo: rosto da diva José Alberto, ela joga em sua peruca laquê. José em cena, pendura o roupão na grade à esquerda, e se direciona ao centro para iniciar o primeiro número da noite.

02:00 - PALHAÇO DE LUXO: BREVE FRAGMENTO UM.

José Alberto In Concert dubla a música En el escenario, de Raquel Olmedo. Logo após, agradecido, caminha até o banco, pega o microfone e fala o seguinte texto, dirigindo-se ao público:

José Alberto: Embaixo de nossas maquiagens, embaixo de nossas perucas (tira peruca), embaixo desse palhaço de luxo existe um ser humano, que ama para ser amado, que respeita para ser respeitado e que espera o carinho e o respeito de todos vocês. Muito obrigado! Muito obrigado mesmo!
Depois de se direcionar para o público, ele deixa o fio do microfone deslizar por suas mãos e vai soltando devagar o microfone a té que ele encoste no chão. Cansado, José, pega sua taça com o suco Detox, sua bombinha para asma, seu leque e assenta-se para descansar as pernas e respirar melhor. Nessa cena há uma certa intimidade de bastidor, ele toma o suco Detox com canudinho, enquanto aproveita o momento de relaxamento (como se estivesse em seu camarim). José se direciona ao público e interage com .

José Alberto: Ai que delícia! Ai!! Que delícia! Você aceita? Aceita? Não? Você não sabe o que você tá perdendo!!! Este é um suco verde, mais conhecido como suco Detox. O Sanches faz todos os dias para mim, ele coloca limão, couve, hortelã, laranja, antes ele colocava abacaxi mas eu não gosto muito não e colocava também duas gotinhas de adoçante. Mas eu já pedi para ele parar com isso. Porque eu acho que estou precisando de perder uns quilinhos. Eu acho não! Eu estou precisando perder uns quilinhos. Você não acham?! Meu nome é José Alberto, tenho 66 anos e há 38 sou a tor transformista. Eu nunca quis mudar meu nome para fazer shows, só acrescentei o In Concert. Porque eu acho que a graça é essa, ser um homem e fazer o papel de uma mulher, subir nos palcos e interpretar uma cantora, uma grande diva. Isso me fascina muito! Eu já pensei sim em me transformar em mulher. Inclusive, deixa eu te contar um segredo, há uns 20, 30 anos atrás, eu tive um 


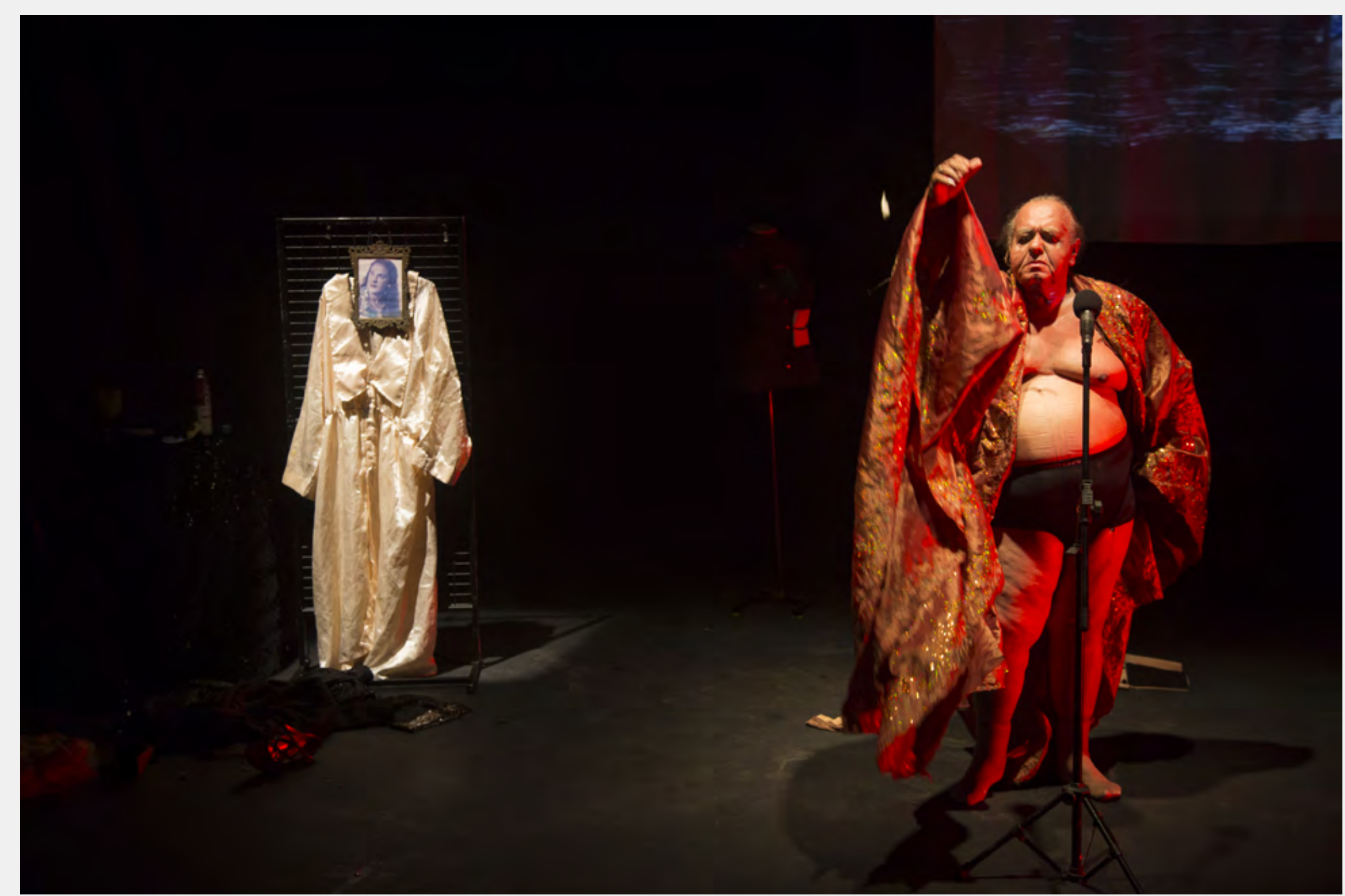


namorado, um francês, piloto de avião, olha o nome gente: Serge Fred Mandelier. Ele queria porque queria que eu me operasse para se casar comigo. Eu morria de vontade! Mas o a mor e respeito para minha família sempre foi maior. Se eu operasse, ja mais poderia voltar. Imagina a cena, um dia eu voltando, e chegando em casa e falando para os meus pais, este é meu marido, hoje sou mulher. (com seriedade) Meu pai, me daria um tiro e minha mãe morreria do coração! Hoje as coisas são mais fáceis, mas no meu tempo era muito difícil. Eu mesmo sempre sonhei em fazer um show em homenagem pra minha mãe, mas nunca teve como. Tem uma música da Rocío Jurado, Algo se me fué contigo madre, que é perfeita! Eu não acho que você escolhe ser gay não! Se vocês (levanta do banco) me perguntassem "José na próxima encarnação você gostaria de voltar homem, mulher ou gay?", eu lhes responderia. (indignado) Homem? De jeito nenhum! Gay? Ja mais! Passar por tudo que eu passei? Não, não... eu gostaria de vir é uma bela de uma mulher (abre o leque e sai, em direção à grade, bebendo seu suco verde, simultaneamente, um vídeo começa a ser exibido.).

José deixa seu leque e sua taça de suco na mesa. Vai para trás da grade pegar seu vestido de Alcione para vesti-lo. Enquanto isso, na tela são exibidas imagens de José em um cômodo de sua casa, onde ele guarda os mais de 600 vestidos, 200 pares de sapato e suas 180 perucas. Ele está ali procurando, nesse universo de figurinos, um especial, e ao procura-lo o ator transformista se mistura em meio aos tecidos, cores, paetês e plumas. Ele encontra e mostra seu primeiro vestido, usado em seu show de estreia em 1980 ocasião que ele interpretou Ângela Maria. Logo depois, outras imagens, vestígios memorativos, vão aparecendo, são fragmentos de shows que ele fez ao longo de sua carreira nas casas de shows e boates de Belo Horizonte. Este vídeo acaba e José se coloca à frente para continuar a conversar com seu público.

$X X: X X$ - PANORAMA DOS ANOS 80 OU UM ROUPÃO PARA UM ESCAPE: BREVE FRAGMENTO DOIS

Durante esse breve fragmento se inicia um vídeo que é manipulado de acordo com o andamento da cena, neste vídeo se compõe de colagens de fotos, notícias de jornais e manchetes para a construção memorialística do texto testemunhal que será dito por José. As fotos revela m imagens das artistas transformistas, travestis e trans mineiras de Belo Horizonte, que marcaram e fizeram história a partir dos anos 60 e que tem ligação afetiva direta com o ator. Manchetes de notícias constroem um panorama documental para o testemunho de José. Notícias como 
A misteriosa doença dos homossexuais. Primeiro aparecem manchas roxas na pele. Depois o mal se infiltra nos Sistemas Digestivo e Linfático. 09.01.1982, Revista Manchete]

[Markito, o costureiro das estrelas, será enterrado em Uberaba. 07.06.1983]

[Markito sepultado ontem... possivelmente vítima de deficiência imunológica.08.06.1983] - Markito é considerado o primeiro brasileiro vitimado pelo HIV.

[Delegacia da vadiagem vai sanear Afonso Pena e a Praça Raul Soares. 07.11.1973, Diário da Tarde]

As bonecas estão dando muito trabalho. 02.07.1978, Diário da Tarde]

[Segundo DP começou campanha e a meta é "limpar" cidade. 21.12.1985, Diário da Tarde,]

[Delegacia mostra obra em costumes. 31.12.1987, Diário da Tarde.]

José Alberto: Final dos anos 80, eu tinha 28 anos, por aí Nesta época, eu já montava para sair para as discotecas e fazer shows em boates. Era o auge em Belo Horizonte, não tem como não lembrar da Fashion, Blue Boy, La Rue Discothéque e outra mais... ah! E a Rua da Lama, atrás da Igreja São José! A glória! E as pegações no Parque Municipal e na Avenida Afonso Pena?! Um luxo! E o Cine
Brasil e o Candelária, as pegações corriam soltas. E Sophia de Carlo, a pioneira! De Nero, o mito! Ira Velásquez, minha grande diva! Michelle Loren, a maravilhosa! Nossa Coquita Pára raio! Cacá Morais, nossa querida Vanusa. Wagner Mamãe! Carlinhos Brasil, nosso eterno caricato! Safira Bengell, a grande diva! Fernando Montenegro, a Fafá de Belém! Valéria, a grande, a eterna estrela das noites e Paulete Star, a perigosa. As duas in memorian. Ta mbém foi uma época muito difícil, de uma hora para outra eu perdia um amigo. E tinha ta mbém a "costumes", a polícia que vinha e prendia a gente. Passei uma noite na cadeia presa e foi terrível, gente.. terrível! Mas nada, nada, tirava o brilho da noite! Meus pais e meus irmãos não sabiam de nada, aliás nunca souberam, eu sou filho daquela tal fa mília tradicional mineira. Eu esperava dar $23 \mathrm{~h} 30$ nos finais de semana, pois era a hora que meus pais dormiam e meus irmãos já haviam saído e aí eu ia para o banheiro para me maquiar e me montar, assim que eles dormiam eu saía nas pontas dos pés, passava em frente a porta do quarto deles e ia feliz para as noitadas da vida. Num sábado, eu tinha um show para fazer na boate La Rue, ia fazer minha grande diva Shirley Bassey e fiz tudo direitinho, como sempre, só que quando eu cheguei na varanda e bati a mão na maçaneta da porta, ouvi um barulho do outro lado da porta, era meu irmão chegando. Voltei correndo pro banheiro e me tranquei. Ele começou a bater na porta dizendo que 


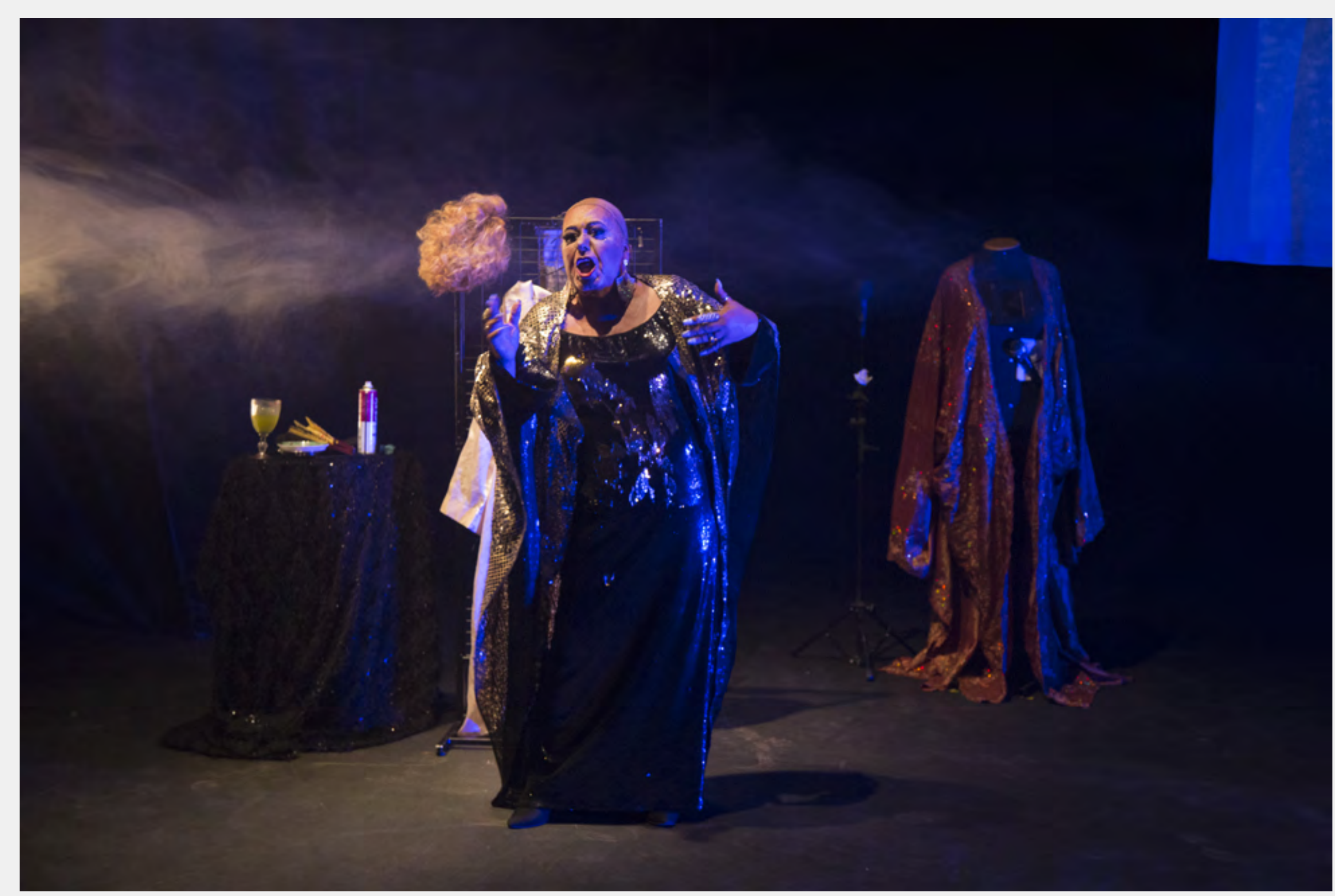


queria entrar, antes de dormir. Abri o chuveiro e respondi que estava tomando banho. Resultado, tive realmente que tomar banho e lá se foi minha maquiagem e o sonho de arrasar naquele dia na boate. Sorte é que meu roupão estava no banheiro e assim pude sair com o vestido e sapa to enrolado debaixo do roupão, para ele não perceber. E a se foi minha noite de glória que tanto planejei, arrasar no show. E o meu arraso terminou na cama, tentando dormir e não conseguir de tanta raiva. (vai em direção ao manequim colocado ao fundo do palco, coloca sua peruca e pega o microfone de strass.).

Inicia a dublagem da música Não deixa o samba morrer, de Alcione, durante esse número no vídeo é exibido trechos da carta escrita por José para Fabrício.

[Quarta-feira, 18/07/2018. 3:45 perdi o sono. Kadê você sono? Sentimento extranho: uma mistura de felicidade e mêdo, pois estão acontecendo coisas comigo que sempre sonhei. Um grande projeto...]

[Será que consigo? Só saberei se tentar e tentarei com muita garra e assim poder mostra para a sociedade o que realmente somos e assim podermos ver mais respeito e dignidade mostrando o que realmente somos e que podemos muito contribuir por um mundo que somos diferentes do que muitos pensam de nós e assim podermos registrar um pouco...]
02:31 - DESCER DO SALTO PARA DENTRO DE SI: BREVE FRAGMENTO TRÊS

Depois da dublagem que finaliza com o refrão Não deixa o samba morrer, não deixa o samba acabar... A partir daqui, o áudio torna-se uma gravação do ator transformista que narra algumas histórias, percepções e olhares dele sobre sua própria vida.

José muda seu ritmo e inicia uma desmontagem da diva In Concert, tira primeiro os cílios postiços, depois os brincos, anéis, colar e sua peruca. Ali fica em pausa a olhar para o público, uma breve respiração. Depois molha sua mão em um óleo, passa em seu rosto e retira a maquiagem, limpando tudo com uma toalha. $\mathrm{Na}$ tela vemos um jogo caleidoscópico de imagens de José se maquiando, porém elas são extremamente misteriosas e não revela m seu rosto. Até aqui o texto que ouvimos em off é

[Uma amiga minha travesti, Sandra Saolin, chegou de Paris, ficou hospedada em minha casa e trouxe o silicone. Ela aplicou em mim nos rosto e em várias clientes minhas. Era colocado com seringa de agulha grossa de aplicar em cavalo, quando você tirava o sangue esguichava tanto que a gente tinha que pregar alguma coisa com Super-Bonder para segurar]

Após o testemunho sobre o silicone e agora mostrando seu rosto desnudo, José retira os suportes, colados uma de 
cada lado de seu rosto, eles seguram suas bochechas que por terem sido preenchidas com silicone, há pelo menos 30 anos, com o tempo cederam à gravidade. E por fim ele revela seus cabelos, retirando a touca de meia que os segura para receber as perucas. Nesse momento uma grande pausa na desmontagem, para capturar, com o olhar, a a tenção do público para eles perceberem que ali diante deles um artista coloca sua existência em destaque. Ele atravessa os tempos e rasga seu corpo para mostrar-se como um sobrevivente de uma temporada - sua própria vida os duros a nos vividos-, inescapável, de caça. Nessa grande pausa ouvimos alguns pedaços de áudio do documentário Temporada de caça (1988), de Rita Moreira,

[Eu tenho muito contra eles, eu tenho muita coisa contra eles. Eu acho que eles não deveriam existir, acho que não deveriam existir. Eu acho que tem mais é que assassinar mesmo. Vocêé a favor que mate? Tem que matar.]

No vídeo, recortes de notícias de jornais da década de 70 e 80 são exibidas, suas manchetes revelam as violências crimes acontecidos contra a sociedade gay brasileira.

[Se você tem um carro e gosta de paquerar pela cidade à noite, cuidado: o cabelereiro José Vieira (26 anos, solteiro, Avenida Amazonas) está procurando uma companhia para divertir-se. 11.01.1972, Jornal Diário da Tarde.
Com o corpo crivado de facadas. Mistério ainda em torno da morte do engenheiro Delgado, cultor da astrologia. 13.03.1976, Diário da Tarde.]

[Batom faz Dênis virar “Denise”. 06.02.1968, Diário da Tarde.]

Retorna o depoimento de José gravado em off, ele em cena sai da pausa e continua sua desmontagem, agora deixando no chão suas vestes, seus sapa tos e enquanto ele fala as imagens continuam a ser exibidas na tela branca. Agora uma foto antiga aparece, seus pais, ele e mais dois irmãos, os três ainda criança. O que ouvimos é as histórias e lembranças de José e sua infância.

Quando criança minhas brincadeiras eram pegar as bonecas de minhas primas e fazer penteados nos cabelos delas. Quando eu não cismava de cortar, cortar não. Estragar o cabelo das bonecas, ai meu pai tinha que comprar outra para dar as minhas primas que choravam sempre. Outras vezes meu pai ficava furioso, pois eu sempre pegava lápis de cor e coloria as paredes todas da casa fazendo desenhos. Mais furioso ele ficava quando uma vizinha falava, este menino quando crescer será cabelereiro ou pintor. E realmente foi o que me tornei, cabelereiro, maquiador e pintor. Um dia eu comprei umas telas e tintas e ai comecei a pintar e comercializar meus trabalhos, onde me encontro até hoje na Feira Hippie de Bh. Só que a vizinha nunca imaginou que eu também seria uma transformista! Ela nunca sonhou isso.] 
Nesse instante do áudio, o rosto do menino José na foto exibida vai tomando toda a tela e ele vai transformando-se no rosto do ator transformista se maquiando, depois aos poucos torna-se José Alberto In Concert jovem, montado de diva, nos a nos 80 e por fim montado de diva atualmente, com 66 anos de idade. E o áudio continua,

[Eu sempre quis mesmo era fazer teatro. Mas meu pai não aceitava. (no vídeo aparece a foto do pai fardado) Ele não aceitava nada que eu fazia, ele só queria que eu fosse militar. O único desejo dele era esse. Ele era Coronel do exército, serviu de soldado na segunda guerra mundial e era do SNI na ditadura. Imagina, eu sou filho de um militar. Eu sofri muito na mão dele. Minha mãe já era mais maleável, (aparece foto da mãe vestida de noiva). Os meus pais nunca me viram montado, mas no final da vida eu que cuidei muito deles. Se eu pudesse voltar no tempo eu iria realizar todo aquele meu sonho antigo.]

$\mathrm{Na}$ tela branca agora é exibida uma foto do casamento dos pais de José Alberto, Raimundo Luciano e Antônia Maria Luciano e a música Algo se me fué contigo madre, de Rocío Jurado se inicia.

02:00 - ALGO QUE SE FOI DIANTE DO QUE FICARÁ: BREVE FRAGMENTO DE UM EPÍLOGO

$\mathrm{O}$ vídeo prossegue e retoma as imagens do início, José Alberto In Concert, de vestido dourado pela cidade, agora o rosto dele aparece. Ele faz movimentos pequenos e está posicionado frente a um muro que tem a frase pichada $O s$ loucos românticos sempre perdem. Ao prosseguir a música a câmera se aproxima do rosto do ator transformista logo depois, numa montagem, aparece a diva Rocío Jurado emocionada em performance num show ao vivo.

Em cena, o a tor continua sua desmontagem, agora tirando as cintas e ficando apenas de cueca. Ele pega o pedestal e sua rosa branca posiciona-o no centro da cena, vai até a grade e coloca o porta retrato com uma foto de sua mãe e por fim, vai a té o ma nequim e veste a capa. As luzes do palco se acendem para que ele faça seu número Para Rocío Jurado. A homenagem a mãe e a realização por ter resistido e agora pisar o tablado de um teatro. José caminha em direção ao pedestal e inicia sua dublagem. A cena finaliza-se com ele beijando a rosa branca e a lançando para cima, logo depois tira sua capa abandonando-a no chão.

No vídeo a cantora, beija uma rosa branca e joga para cima. Antes disso, os seguintes dizeres aparecem na tela branca:

[Foi há 10 anos atrás que o vi, como uma miragem, no meio de intermitentes luzes de uma boate. Ele estava sentado e era reverenciado pelas artistas que ali estavam.] 
FIM

Atuação e textos: José Alberto In Concert

Concepção, direção cênica e dramaturgia: Fabrício

Trindade

Consultoria dramatúrgica: Éder Rodrigues

Consultoria histórica: Luiz Morando

Iluminação: Marina Arthuzzi

Produção: João Cardoso e Rafael De La Savia 

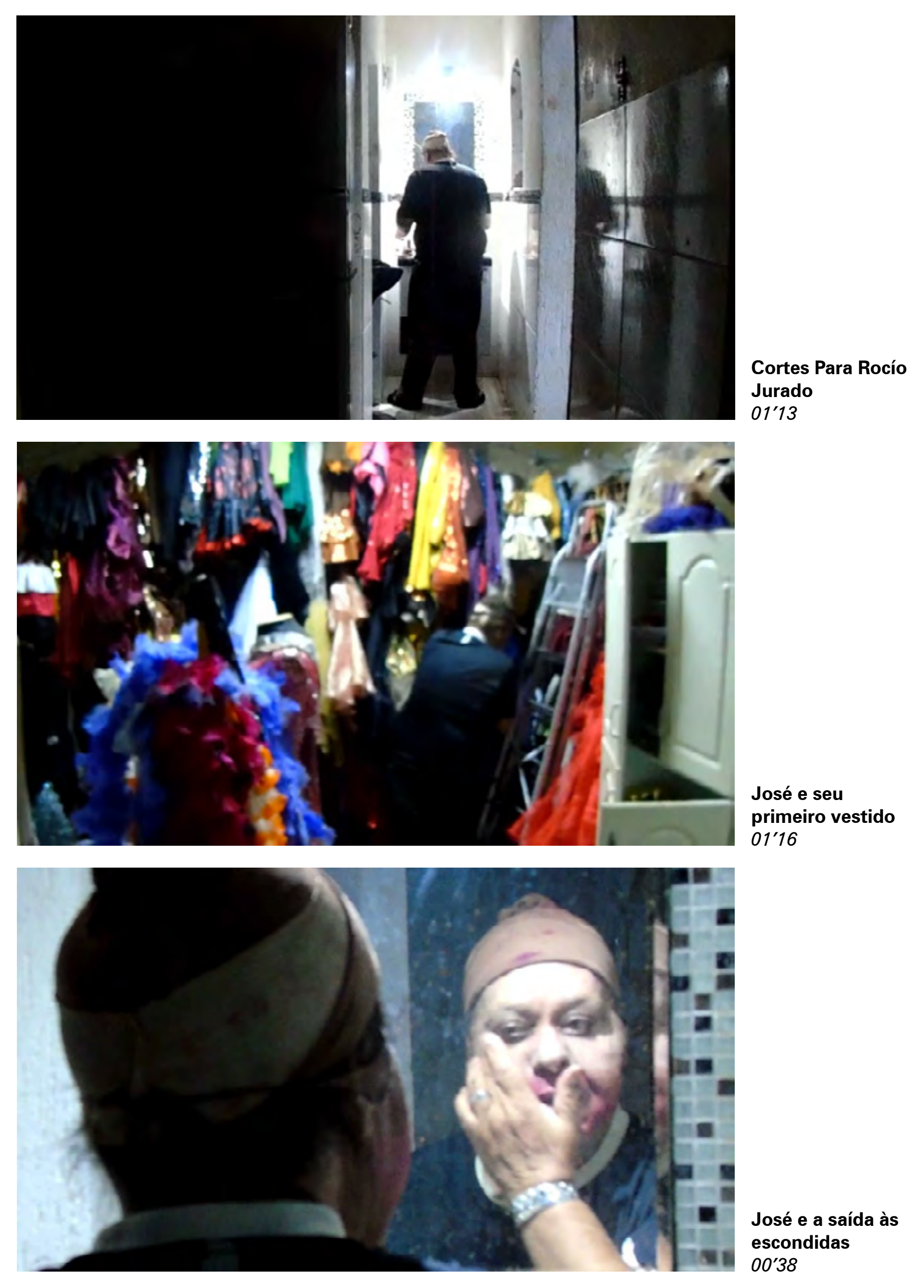